\title{
KEMAMPUAN POLISAKARIDA MANNAN SEBAGAI ORAL AJUVAN VAKSIN AVIAN INFLUENZA PADA AYAM BROILER
}

\author{
(Polysaccharides Contain Mannan from Palm Kernel Meal as an Oral \\ Adjuvant of the Avian Influenza in Broiler Chicken)
}

\author{
Syahruddin'), Kamaluddin Zarkasie' ${ }^{2)}$, Yatno $^{3)}$, R. Mutia年, dan Nahrowi ${ }^{* 4)}$ \\ ${ }^{1}$ Jurusan Peternakan Fakultas Pertanian Universitas Negeri Gorontalo \\ 2 IPB-Shigeta \\ ${ }^{3}$ Fakultas Peternakan Universitas Jambi \\ ${ }^{4}$ Fakultas Peternakan Institut Pertanian Bogor \\ *Coresponding Author: Email: nahrowi@ipb.ac.id
}

\begin{abstract}
The objective of this study was to evaluate the ability of PM from PKM as an oral adjuvant of the avian influenza (AI) vaccine against an increase in AI H5N1 antibody titer and immunoglobulin A (IgA) serum in 30 heads of broiler aged 1-6 weeks. This study used a completely randomized design with 5 treatments and 3 replications. The treatments conducted are $\mathrm{R} 0 \mathrm{~A}=$ broiler not vaccination, $\mathrm{R} 0 \mathrm{~B}=$ broiler vaccination with $\mathrm{H} 5 \mathrm{~N} 1$ antigen $+0 \mu \mathrm{g}$ PM, R1 = broiler vaccination with $\mathrm{H} 5 \mathrm{~N} 1$ antigen $+50 \mu \mathrm{g}$ PM, R2 = broiler vaccination with H5N1 antigen $+100 \mu \mathrm{g}$ PM, and R3 = broiler vaccination with H5N1 antigen $+200 \mu \mathrm{g}$ PM. The results showed that the treatment did not reduce broiler body weight (PM is not toxic). AI H5N1 antibody titer increased significantly affected $(\mathrm{P}<0.05)$ one week after the first vaccination, serum IgA of broiler also increased significantly affected $(\mathrm{P}<0.05)$ two weeks after the second vaccination. R3 treatment $(200 \mu \mathrm{g}$ PM) produce higher $\mathrm{HI}$ antibody titer $\leq 5 \log 2$ and serum IgA 1.6 fold higher compared with those of broiler received R0A and R0B. It can be concluded that PM can increase the immune response in broiler chickens and can be used as an adjuvant for inactive AI vaccine.
\end{abstract}

Keywords: Avian Influenza vaccine, Broiler chick, Mannan, Oral adjuvant, Palm kernel meal

ABSTRAK

Tujuan penelitian ini adalah menguji kemampuan PM dari BIS sebagai oral ajuvan vaksin avian influenza (AI) terhadap peningkatan titer antibodi AI H5N1 dan Imunoglobulin A (IgA) pada 30 ekor ayam broiler yang berumur 1-6 minggu. Penelitian ini menggunakan rancangan acak lengkap (RAL) yang terdiri atas 5 perlakuan dan 3 ulangan. Perlakuan yang diberikan yaitu $\mathrm{R} 0 \mathrm{~A}=$ tidak divaksinasi, $\mathrm{R} 0 \mathrm{~B}=$ vaksinasi dengan antigen $\mathrm{H} 5 \mathrm{~N} 1+0 \mu \mathrm{g}$ PM, R1 = vaksinasi dengan antigen $\mathrm{H} 5 \mathrm{~N} 1+50 \mu \mathrm{g}$ PM, R2 = vaksinasi dengan antigen $\mathrm{H} 5 \mathrm{~N} 1+100 \mu \mathrm{g}$ PM, R3 = vaksinasi dengan antigen H5N1 + $200 \mu \mathrm{g}$ PM. Hasil penelitian menunjukkan bahwa perlakuan tidak menurunkan bobot badan ayam (PM tidak bersifat toksik). Titer antibodi AI H5N1 meningkat secara nyata $(\mathrm{P}<0.05)$ satu minggu setelah vaksinasi pertama, Serum IgA ayam broiler juga meningkat secara nyata $(\mathrm{P}<0.05)$ dua minggu setelah vaksinasi kedua. Perlakuan R3 (200 $\mu \mathrm{g}$ PM) mampu menghasilkan titer antibodi HI lebih tinggi $\leq 5 \log 2$ dan serum IgA 1.6 kali lebih tinggi dibandingkan dengan vaksinasi tanpa penambahan PM (R0A dan R0B). Penggunan PM mampu meningkatkan respon imun pada ayam broiler dan dapat digunakan sebagai bahan ajuvan vaksin avian influenza inaktif.

Kata kunci: Ayam broiler, Bungkil inti sawit, Mannan, Oral ajuvan, Vaksin avian influenza 


\section{PENDAHULUAN}

Kelapa sawit adalah salah satu komoditas perkebunan utama di Indonesia tersebar pulau Sumatra, Kalimantan, Sulawesi, Papua, dan Jawa. Pengolahan kelapa sawit menghasilkan minyak sawit dan bungkil inti sawit.

Bungkil inti sawit (BIS) merupakan hasil samping dari pengolahan inti sawit untuk mendapatkan minyak inti sawit. Penggunaan BIS sebagai pakan potensial telah banyak dilaporkan pada ruminansia dan ternak unggas. Nahrowi, dkk (2005) melaporkan bahwa konten PCK Mannose mencapai 68,9\% dan ketersediaannya berkesinambungan atau terjamin. Kandungan mannan yang tinggi serta faktor pembatas juga dapat dianggap sebagai potensi untuk mendapatkan tambahan pakan prebiotik yang akan meningkatkan kesehatan ternak

Ketersedian BIS di Indonesia cukup tinggi, namun penggunaan dalam campuran pakan unggas masih terbatas karena BIS mengandung $\beta$-mannan yang tinggi dan dapat bersifat sebagai anti nutrisi. Namun disisi lain, polisakarida mannan (PM) dapat berfungsi meningkatkan respon kekebalan tubuh dan pengendali beberapa mikroba patogen yang merugikan ternak. Tafsin (2007) melaporkan bahwa mannan dari BIS menunjukkan adanya aktivitas sebagai immunostimulan yang dapat memperbaiki kesehatan ternak unggas. Penggunaan MOS dilaporkan dapat memperbaiki kekebalan dengan meningkatnya aktifitas fagosit dari makrofag dan meningkatkan level Imunoglobulin (Ig) (Lyons 1996). Individu yang defisien mannan binding lectin (MBL) menyebabkan peningkatan mudahnya terkena infeksi penyakit, khusus pada sistem mukosanya (Ross et al., 2001). Faktor utama pertahanan sistem kekebalan mukosa adalah immunoglobulin A.

Di lain pihak, salah satu penyakit yang masih mengancam dunia perunggasan adalah penyakit avian influenza (AI). Penanggulangan penyakit AI dapat ditempuh diantaranya melalui program vaksinasi untuk memberikan perlindungan terhadap infeksi penyakit AI. Vaksin AI yang digunakan dewasa ini adalah vaksin killed dalam ajuvan oil emulsion, yang diberikan secara intramuskuler atau subkutan. Selain dari oil emulsion dipandang perlu untuk mendapatkan suatu bahan ajuvan yang aman serta dapat diberikan secara oral atau lewat air minum, dengan maksud merangsang sistem kekebalan melalui mukosa. Perbaikan sistem kekebalan mukosa merupakan trend baru dalam upaya mencegah infeksi penyakit menular melalui mukosa. Penggunaan polisakarida mengandung mannan (PM) dari BIS sebagai bahan ajuvan oral vaksin AI terhadap peningkatan respon kekebalan tubuh ayam broiler sangat penting dilakukan dalam meningkatkan immunitas tubuh ternak ayam broiler pasca vaksinasi. Apakah penggunna polisakarida 
mengandung mannan (PM) dari BIS sebagai bahan ajuvan oral dapat memberikan respon terhadap kekebalan tubuh? Tujuan penelitian ini untuk mengetahui penggunna polisakarida mengandung mannan (PM) dari BIS sebagai bahan ajuvan oral dapat memberikan respon terhadap kekebalan tubuh

\section{MATERI DAN METODE}

Penelitian ini menggunakan polisakarida mengandung mannan (PM) yang diperoleh dari proses ekstraksi kombinasi fisik kimia bungkil inti sawit (BIS) (Ramli et al., 2005). Antigen yang digunakan yaitu antigen H5N1 inaktif (Strain A/CK/Legok/2003 Homolog; 512 $\mathrm{HAU} / \mathrm{ml}$ ) yang diperoleh dari PT. IPB-Shigeta. Sedangkan ayam broiler yang digunakan sebanyak 30 ekor strain Ross yang berumur 7 hari dengan jenis kelamin campuran (unsexed). Pemeliharaan ayam broiler dilaksanakan di kandang $\mathrm{C}$ Fapet-IPB.

Upaya mengetahui adanya respon polisakarida mannan dari BIS sebagai oral ajuvan vaksin $\mathrm{AI}$ terhadap peningkatan respon kekebalan tubuh ayam broiler, dilakukan dengan vaksinasi secara oral (dicekok). Dosis vaksin yang diberikan $0.25 \mathrm{ml} / \mathrm{ekor}$ yang mengandung $0.1 \mathrm{ml}$ antigen H5N1 ditambah PM dari BIS sesuai dengan perlakuan.

Vaksinasi terhadap ayam broiler dilakukan sebanyak dua kali. Vaksinasi pertama dilakukan pada umur satu minggu (7 hari), selanjutnya vaksinasi kedua (booster) dilakukan pada umur tiga minggu
(21 hari). Pengambilan sampel darah dilakukan setiap minggu, sebanyak satu ekor pada tiap-tiap ulangan. Sampel darah yang diperoleh diambil serumnya kemudian disimpan pada suhu $20^{\circ} \mathrm{C}$ sampai saat pemeriksaan. Selain itu bobot badan ayam broiler ditimbang setiap minggu selama penelitian. Pemeriksaan titer antibodi AI dan optical density (OD) IgA serum ayam broiler dilaksanakan di Laboratorium Imunologi FKH-IPB.

Penelitian ini menggunakan rancangan acak lengkap (RAL) dengan lima perlakuan dan setiap perlakuan diberi ulangan sebanyak tiga kali. Model matematika yang digunakan untuk rancangan tersebut menurut Gaspersz (1991) adalah:

$$
Y_{i j}=u+T_{i}+\epsilon_{i j}
$$

Keterangan:

$Y_{i j}=$ Hasil pengamatan dari perlakuan ke-i dan ulangan ke-j

$u$ = Rata-rata pengamatan

$T_{i}=$ Pengaruh perlakuan ke-i $(\mathrm{i}=1,2,3,4$,

$\epsilon_{i j}=$ Pengaruh galat perlakuan ke-i dan ulangan ke-j $(j=1,2,3)$

Perlakuan yang diberikan yaitu:

1. $\mathrm{ROA}=$ tidak divaksinasi,

2. $\mathrm{ROB}=$ vaksinasi dengan antigen $\mathrm{H} 5 \mathrm{~N} 1+0 \mu \mathrm{g}$ Polisakarida mannan BIS,

3. $\mathrm{R} 1=$ vaksinasi dengan antigen $\mathrm{H} 5 \mathrm{~N} 1+50 \mu \mathrm{g}$ Polisakarida mannan BIS,

4. $\mathrm{R} 2$ = vaksinasi dengan antigen $\mathrm{H} 5 \mathrm{~N} 1+100 \mu \mathrm{g}$ Polisakarida mannan BIS dan,

5. $\mathrm{R} 3=$ vaksinasi dengan antigen H5N1 + $200 \mu \mathrm{g}$ Polisakarida mannan BIS. 
Parameter yang diamati yaitu pertambahan bobot badan ayam broiler umur 7-21 hari (g/ekor) dan umur 21-42 hari (g/ekor), bobot badan akhir umur 42 hari (g/ekor), evaluasi titer antibodi AI ayam broiler (HI log2) dengan menggunakan uji Haemagglutination Inhibition (HI Test) (OIE, 2004) dan pengukuran optical density (OD) pada panjang gelombang $(\lambda) 615 \mathrm{~nm}$ untuk IgA serum ayam broiler umur 1-6 minggu dengan menggunakan metode Enzyme-linked immunosorbent assay (ELISA) (Crowther, 1995). Analisis data menggunakan analisis of variance dengan uji wilayah berganda Duncan (Gaspersz, 1991).

\section{HASIL DAN PEMBAHASAN}

\section{Pertambahan Bobot Badan (PBB) dan Bobot Badan Akhir Ayam Broiler}

Pengaruh penggunaan polisakarida mannan dari BIS sebagai oral ajuvan vaksin AI terhadap pertambahan bobot badan (PBB) dan bobot akhir ayam broiler umur 7-42 hari dapat dilihat pada Gambar 1.

Perlakuan tidak berpengaruh nyata $\quad(\mathrm{P}>0.05) \quad$ terhadap pertambahan bobot badan ayam broiler fase starter (umur 7-21 hari) maupun fase finisher (umur 21-42 hari) (Gambar 1a). Demikian juga terhadap bobot badan akhir ayam broiler (Gambar 1b). Namun demikian perlakuan R1 (vaksinasi dengan antigen $\mathrm{H} 5 \mathrm{~N} 1+50 \mu \mathrm{g}$ PM) selama lima minggu pengamatan memperlihatkan pertumbuhan yang lebih baik dibandingkan yang lain. Hal ini menunjukkan bahwa polisakarida mannan (PM) sebagai oral ajuvan vaksin tidak menurunkan bobot badan atau tidak bersifat toksik.

Vaksinasi dengan antigen H5N1+PM secara oral tidak mempengaruhi PBB maupun bobot badan akhir ayam. Hal tersebut kemungkinan disebabkan oleh pengaruh antigen bersama PM lebih banyak untuk merangsang imunogenisitas, sehingga pengaruhnya terhadap bobot badan tidak tampak. Pakaya et al., (2019) bahwa secara umum pertambahan bobot badan akan dipengaruhi oleh jumlah konsumsi ransum dan kandungan nutrisi yang terdapat dalam ransum ayam.

Takahashi et al. (2000) menyatakan bahwa respon cekaman akibat perangsangan sistem kekebalan akan menimbulkan efek tambahan terhadap penampilan ternak karena lebih banyak nutrien yang terbagi untuk pembentukan antibodi dan perkembangan organ kekebalan sehingga menurunkan ketersediaan nutrien untuk pertumbuhan 


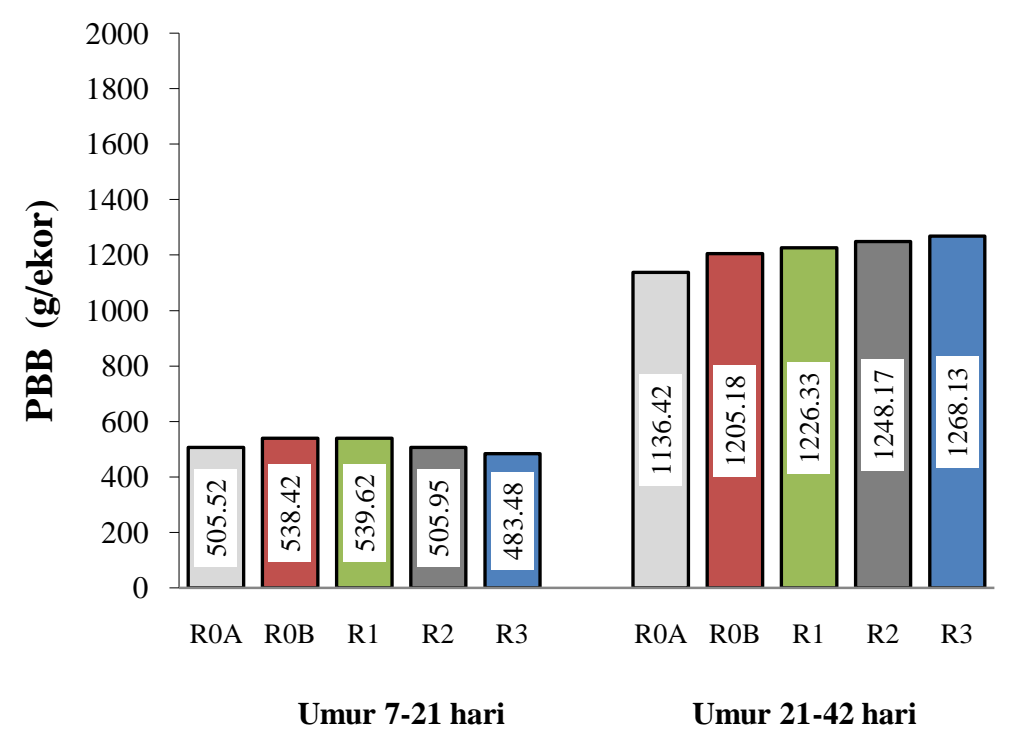

(a)

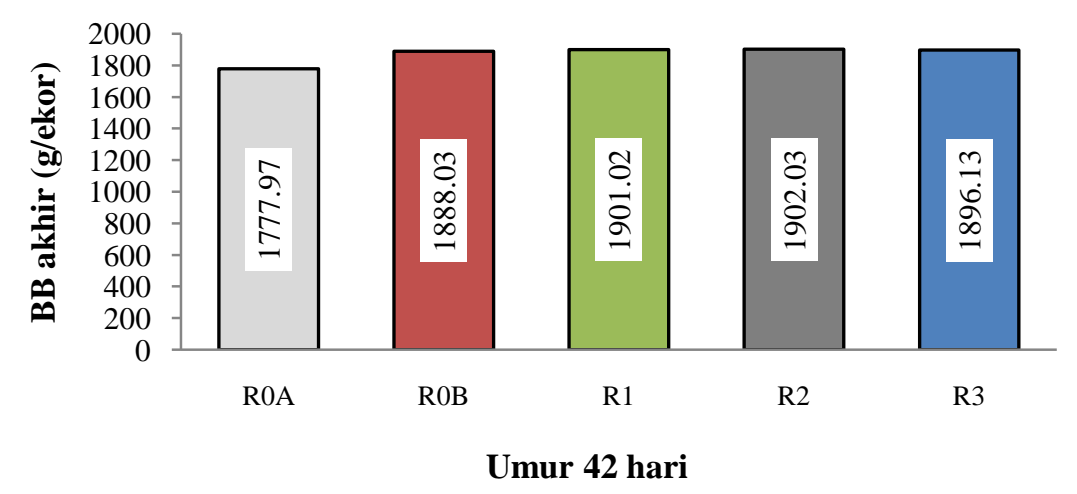

(b)

Gambar 1. (a) Pengaruh PM sebagai oral ajuvan vaksin AI terhadap PBB fase starter dan finisher, (b) bobot badan akhir ayam broiler.

Klasing (1998) menyatakan bahwa efek perangsangan sistem kekebalan tidak mempengaruhi pertumbuhan karena kebutuhan jumlah nutrien untuk sistem kekebalan relatif lebih kecil dibanding untuk pertumbuhan. Stress kekebalan yang diakibatkan efek imunostimulan berbeda dengan stress yang diakibatkan infeksi yang dapat menyebabkan reaksi keseluruhan dari tubuh yang meliputi perubahan fisiologis dan \begin{tabular}{l} 
metabolis seperti demam, \\
menurunnya konsumsi dan \\
menigkatnya katabolisme nutrien. \\
\multicolumn{2}{c}{ Beberapa peneliti yang }
\end{tabular} menggunakan bahan yang sejenis yaitu mannanoligosakarida (MOS), penggunaan 0,05\% MOS (Flemming et al., 2004), dan 0,3\% MOS tidak berpengaruh terhadap pertambahan bobot badan (Shafey et al., 2001). Sebaliknya, laporan yang menyebutkan adanya peningkatan 
PBB pada ayam broiler dilaporkan Waldroup et al. (2003).

Penggunaan bahan yang sama yaitu polisakarida mannan dari BIS dilaporkan oleh Tafsin (2007) bahwa penggunaan polisakarida mannan sampai tingkat 3000 ppm dalam ransum dapat meningkatkan PBB pada ayam broiler. Selanjutnya dinyatakan bahwa penggunaan bahan yang mengandung komponen PM atau MOS dan pengaruhnya terhadap pertumbuhan tergantung pada level mannosa yang digunakan.

\section{Titer antibodi AI H5N1 ayam broiler}

Pengaruh

penggunaan polisakarida mannan (PM) dari BIS sebagai oral ajuvan terhadap titer antibodi AI H5N1 ayam broiler dapat dilihat pada Tabel 1.

Tabel 1. Pengaruh penggunaan polisakarida mannan (PM) dari BIS sebagai oral ajuvan vaksin AI terhadap titer antibodi AI ayam broiler (HI log2)

\begin{tabular}{|c|c|c|c|c|c|c|}
\hline \multirow[t]{2}{*}{ Perlakuan } & \multirow[t]{2}{*}{$\begin{array}{l}\text { sebelum } \\
\text { vaksinasi }\end{array}$} & \multicolumn{2}{|c|}{$\begin{array}{c}\text { Minggu setelah } \\
\text { vaksinasi pertama }\end{array}$} & \multicolumn{3}{|c|}{$\begin{array}{l}\text { Minggu setelah } \\
\text { vaksinasi kedua }\end{array}$} \\
\hline & & 1 & 2 & 1 & 2 & 3 \\
\hline R0A & $3.33 \pm 1.15$ & $2.00 \pm 0.00^{c}$ & $3.33 \pm 0.58$ & $3.33 \pm 0.58^{b}$ & $3.33 \pm 0.58$ & $3.00 \pm 1.00^{b}$ \\
\hline R0B & $4.00 \pm 0.00$ & $4.00 \pm 1.00^{b}$ & $4.33 \pm 0.58$ & $3.67 \pm 1.15^{\mathrm{ab}}$ & $4.66 \pm 1.53$ & $4.33 \pm 1.15^{\mathrm{ab}}$ \\
\hline $\mathrm{R} 1$ & $3.67 \pm 1.15$ & $5.00 \pm 0.00^{a}$ & $4.00 \pm 1.00$ & $4.33 \pm 0.58 \mathrm{ab}$ & $4.33 \pm 0.58$ & $5.67 \pm 2.08^{a}$ \\
\hline $\mathrm{R} 2$ & $3.33 \pm 0.58$ & $4.67 \pm 0.58 \mathrm{ab}$ & $4.00 \pm 0.00$ & $5.00 \pm 1.00^{a}$ & $3.67 \pm 0.58$ & $5.67 \pm 1.53^{\mathrm{a}}$ \\
\hline R3 & $3.33 \pm 0.58$ & $5.00 \pm 0.00^{a}$ & $4.33 \pm 0.58$ & $4.33 \pm 0.58 \mathrm{ab}$ & $4.00 \pm 0.00$ & $5.33 \pm 0.58 \mathrm{ab}$ \\
\hline
\end{tabular}

Keterangan: Superskrip huruf abc yang berbeda pada kolom yang sama menunjukkan beda nyata $(\mathrm{P}<0.05)$. R0A (tidak divaksinasi), R0B (vaksinasi dengan antigen H5N1 + $0 \mu \mathrm{g} P \mathrm{PM}), \mathrm{R} 1$ (vaksinasi dengan antigen H5N1 + $50 \mu \mathrm{g}$ PM), R2 (vaksinasi dengan antigen H5N1 + $100 \mu \mathrm{g}$ PM), R3 (vaksinasi dengan antigen H5N1 + $200 \mu \mathrm{g}$ PM).

Pengamatan mingguan menunjukkan bahwa sebelum vaksinasi nilai titer HI antara 3.33 $4.00 \log 2$. Satu minggu setelah vaksinasi pertama, perlakuan (vaksinasi dengan antigen $\mathrm{H} 5 \mathrm{~N} 1+\mathrm{PM})$ berbeda nyata $(\mathrm{P}<0.05)$ terhadap titer antibodi AI ayam broiler. Perlakuan R1, R2 dan R3 nyata lebih tinggi dibandingkan dengan R0B (vaksinasi dengan antigen H5N1 tanpa PM) (5.00; 4.67; 5.00 vs $4.00 \log 2)$. Vaksinasi dengan antigen $\mathrm{H} 5 \mathrm{~N} 1$ secara oral berbeda nyata $(\mathrm{P}<0.05)$ terhadap titer antibodi AI H5N1 dibandingkan dengan R0A (tidak divaksinasi). Vaksinasi dengan antigen H5N1 ditambah PM maupun tanpa PM (R0B), rata-rata dapat memberikan titer antibodi AI protektif (4 $\log 2)$ setelah vaksinasi pertama maupun vaksinasi kedua berlangsung. Selanjutnya dua minggu setelah vaksinasi pertama perlakuan tidak berbeda nyata terhadap titer antibodi AI H5N1. Demikian juga dua minggu setelah vaksinasi kedua berlangsung. Titer antibodi AI meningkat kembali tiga minggu setelah vaksinasi kedua.

Hasil pengamatan yang dilakukan menunjukkan bahwa penggunaan 50; 100 dan $200 \mu \mathrm{g}$ PM bersama antigen (perlakuan R1, R2 dan R3) dapat meningkatkan titer 
antibodi AI H5N1 $\leq 1 \log 2(20 \%)$ lebih tinggi dibandingkan vaksinasi tanpa PM (R0B) dalam waktu satu minggu.

Perlakuan R1 dan R2 juga memiliki kecenderungan meningkatkan titer $\mathrm{HI} \leq 1.34 \log 2$ lebih tinggi dibandingkan vaksinasi dengan antigen $\mathrm{H} 5 \mathrm{~N} 1$ sendiri tiga minggu setelah vaksinasi kedua. $\mathrm{Hal}$ ini menunjukkan bahwa komponen mannan dari BIS sebagai oral ajuvan vaksin AI dapat menggertak atau menimbulkan efek yang merangsang sistem kekebalan lebih aktif untuk pembentukan antibodi. Mekanisme bagaimana PM ini dapat menstimulasi pembentukan antibodi belum diketahui secara pasti. Dugaan yang muncul yang mejelaskan fenomena ini bahwa sel pertahanan tubuh dapat mendeteksi kehadiran mikroba karena adanya molekul unik yang disebut pathogenassociated molecular pattern (PAMP) yang akan mengaktifkan sistem kekebalan seperti fagositosis dan jalur lektin. Komponen gula mannosa mempengaruhi sistem kekebalan tubuh dengan jalan merangsang sekresi protein yang dapat mengikat mannosa, dan dikenal dengan istilah mannosa binding lectin (MBL). MBL disintesa di hati dan disekresikan ke dalam serum sebagai komponen dengan fase respon yang bersifat akut. MBL dapat berikatan dengan karbohidrat dari dinding sel bakteri, ragi atau virus (Janeway et al., 2005).

Vaksin AI yang baik akan menimbulkan kekebalan yang lebih tinggi dan berlangsung lama, yakni dalam waktu tiga minggu setelah vaksinasi akan menghasilkan titer antibodi minimal $2^{4}=16$, seperti yang direkomendasikan oleh organisasi kesehatan hewan (OIE 2004). Respons perlakuan dapat mempertahankan titer antibodi AI protektif $\left(2^{4}\right)$ selama lima minggu pengamatan. Walaupun titer antibodi AI protektif yang terbentuk pada ayam broiler tampaknya masih rendah. Hal ini kemungkinan disebabkan oleh pengaruh antibodi maternal yang diperoleh dari induknya yang dapat menghambat pembentukan imunoglobulin, sehingga dapat mempengaruhi keberhasilan dalam vaksinasi. Penghambatan berlangsung sampai antibodi maternal habis, yaitu sekitar 10-20 hari setelah menetas (Tizard, 1982).

Pemberian antigen $+\mathrm{PM}$ secara oral dapat merespons peningkatan titer antibodi AI pada ayam broiler satu minggu setelah vaksinasi kedua berlangsung. Jika melihat dari fenomena tersebut diatas, sebaiknya pemberian vaksinasi pertama dilakukan secara oral dan selanjutnya dapat diberikan secara injeksi atau intranasal. Namun dengan penggunaan PM BIS sebagai ajuvan secara injeksi masih diperlukan kajian mengingat adanya figmen warna coklat dari polisakarida BIS yang dapat mempengaruhi warna daging ayam broiler. Penggunaan bahan sejenis dengan PM yaitu mannanoligosakarida (MOS) telah dilaporkan oleh Pietersz et al. (2008) 
bahwa vaksinasi dengan antigen H5N1 ditambah mannosa dari Saccharomyces cerevisiae secara intranasal pada tikus, titer antibodi $\mathrm{HI}$ lebih tinggi dibandingkan vaksinasi dengan antigen $\mathrm{H} 5 \mathrm{~N} 1$ sendiri (HI titer 80 vs 40) 12 hari setelah vaksinasi pertama. Selanjutnya penggunaan bahan yang sama yaitu PM dari BIS telah dilaporkan oleh Tafsin (2007) bahwa penggunaan 1000, 3000 dan 4000 ppm PM dalam ransum nyata meningkatkan titer IBD dibandingkan dengan kontrol. Hasil tersebut menunjukkan adanya aktivitas immunostimulan dari PM pada ternak ayam.

\section{IgA Serum Ayam Broiler}

Pengaruh penggunaan PM dari BIS sebagai oral ajuvan vaksin AI terhadap optical density (OD) IgA serum ayam broiler umur 1- 6 minggu disajikan pada Gambar 2.

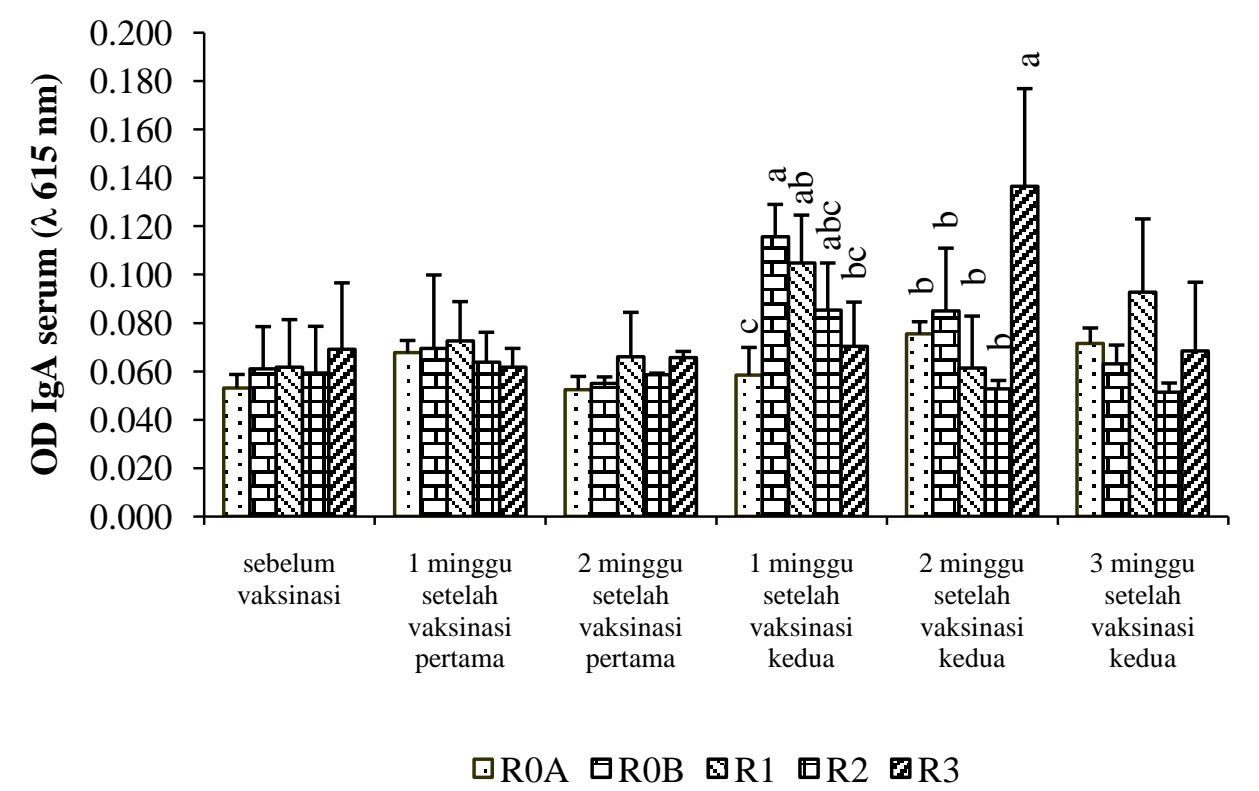

Gambar 2. Pengaruh penggunaan PM dari BIS sebagai oral ajuvan vaksin AI terhadap optical density (OD) IgA serum ayam broiler umur 1- 6 minggu.

Gambar 2 menunjukkan bahwa satu minggu setelah vaksinasi kedua (booster), pemberian vaksin secara oral perlakuan $\mathrm{R} 0 \mathrm{~B}$ dan R1 nyata lebih tinggi $(\mathrm{P}<0.05)$ terhadap peningkatan OD IgA serum dibandingkan dengan ayam yang tidak divaksinasi (R0A). Hasil ini mengindikasikan bahwa vaksinasi dengan antigen $\mathrm{H} 5 \mathrm{~N} 1$ secara oral mampu merespon peningkatan IgA serum. Respon 
perlakuan terhadap peningkatan IgA serum terlihat meningkat di dua minggu setelah vaksinasi kedua berlangsung, dimana perlakuan R3 (200 $\mu \mathrm{g} \quad \mathrm{PM})$ nyata $(\mathrm{P}<0.05)$ meningkatkan OD IgA dibandingkan dengan OD IgA ROB dan R0A (OD; $0.137 \pm 0.040$ vs 0.085 \pm 0.026 dan $0.076 \pm 0.005)$. Hal ini menunjukkan bahwa penggunaan PM sebagai oral adjuvan vaksin AI dapat meningkatkan IgA serum ayam broiler. Namun demikian respon PM terhadap peningkatan titer antibodi AI terlihat lebih cepat (satu minggu setelah vaksinasi pertama) dibandingkan peningkatan IgA serum.

Mekanisme bagaimana antigen H5N1 ditambah PM ini dapat menstimulasi pembentukan imunoglobulin A belum diketahui secara pasti. Namun IgA dibuat oleh sel plasma di dalam jaringan limfoid yang berhubungan dengan usus dalam menanggapi ransangan antigen setempat, biasanya IgA hanya berupa komponen minor dalam serum darah. Berbeda dengan IgG yang terdapat dalam konsentrasi tertinggi dalam serum darah hewan. Karena ukuran yang relatif kecil maka zat ini lebih mudah keluar dari pembuluh darah dibandingkan molekul imunoglobulin yang lain, oleh karena itu cepat mengambil bagian utama dalam mekanisme pertahanan pada ruang jaringan dan permukaan tubuh (Tizard, 1982). Namun demikian diduga antigen H5N1 bersama PM mengaktifkan respon imun sistemik atau sistem imun keseluruhan.

Konsentrasi IgA di dalam serum maupun mukosa (IgA sekretori) ayam belum diketahui secara pasti tingkat yang protektif terhadap suatu penyakit tertentu. Namun demikian Tizard (1982) menyatakan bahwa tingkat imunoglobulin serum masingmasing: IgG; 300-700 mg/100 ml serum, IgM; 120-250 mg/100 ml serum dan IgA; 30-60 mg/100 ml serum.

Penggunaan bahan sejenis dengan PM yaitu MOS sebagai immunostimulan hasilnya bervariasi. Savage et al. (1996) melaporkan bahwa penambahan Bio-MOS 1-2 kg/ton pakan kalkun starter dapat meningkatkan respon imun tercermin dari meningkatnya IgG serum dan IgA cairan empedu. Selain itu dapat meningkatkan pertambahan bobot badan serta menurunkan konversi ransum. Sebaliknya,

Sauerwein, et al. (2007) meneliti penggunaan ekstrak dinding sel ragi $S$ cerevisiae sebagai immunomodulator pada babi menunjukkan bahwa efeknya terhadap status kekebalan (aktivitas fagosit, konsentrasi IgG dan IgA, dan immunohistokimia) hasilnya tidak konsisten, dan efeknya terhadap peubah usus dan penampilan ternak tidak berbeda nyata. Selanjutnya Spearman (2004) melaporkan bahwa suplementasi Bio-MOS 10 g/ekor/hari tidak dapat meningkatkan konsentrasi IgA serum pada kuda. 


\section{KESIMPULAN}

Dapat disimpulkan bahwa penggunaan $200 \mu \mathrm{g}$ polisakarida mannan (PM) sebagai oral ajuvan vaksin AI H5N1 mampu meningkatkan respon imun pada ayam broiler dan PM dari BIS dapat digunakan sebagai bahan ajuvan vaksin inaktif avian influenza.

\section{DAFTAR PUSTAKA}

Crowther, J.R. (1995). ELISA: Theory and Practice. Humana Press. Totowa, New Jersey.

Dirjen Bina Produksi Perkebunan [Director General of Plantation Production Development 2016 Statistics of plantation (Jakarta: Directorate General of Agriculture Department of Agriculture Department)

Flemming, J.S., Freitas, J.R.S., Fontoura, P., Monthaninhi, N.R., \& Arruda, J.S. (2004). Use of mannanoligosaccharides in broiler feeding. Brazilian Journal of Poultry Science, 6, 159-161.

Gaspersz, V. (1991). Metode Perancangan Percobaan. Penerbit CV. Armico, Bandung.

Janeway, et al. (2005). Immunology. Garland Science, New York.

Klasing, K.C. (1998). Nutritional modulation of resistance to infectious diseases. Poultry Science, 77, 1119-1125.

Lyons, T.P. (1996). Goal 2000: A truly global science based company that responds rapidly to emerging issues. Di dalam: Lyons, T.P., \& Jacques, K.A., editor. Biotechnology in the Feed Industry. Proceedings of Alltech $12^{\text {th }}$ Annual Symposium. (pp. 1-22). Nottingham University Press, Nottingham.

Nahrowi, Wiryawan K G, and Tafsin M (2005) Isolasi dan sifat fisik kimia polisakarida mengandung mannan dari bungkil inti sawit dan dinding sel Penicillium Spp [Isolation and chemical physical properties of polysaccharides containing mannan from palm kernel cake and cell walls] Makalah Seminar AINI [AINI Seminar Paper] (Malang)

[OIE] Office International des Epizooties. 2004. Manual of Diagnostic tests and vaccines for terrestrial animals: Avian Influenza. $5^{\text {th }} \quad$ Ed. http://www.oie.int/eng/nor mes/mmanual/A_00037.htm

Pakaya, S.A., Zainudin, S., \& Dako, S. (2019). Performa ayam kampung super yang diberi level penambahan tepung kulit kakao (Theobroma cacao, L.) fermentasi dalam ransum. Jambura Journal of Animal Science, $\quad 1(2), \quad 40-45$. 
https://doi.org/10.35900/jjas. v1i2.2603

Pietersz, G.A., Esparon, S.E., Proudfoot, O., penemu; Patent Cooperation Treaty (PCT). 3 April 2008. Flu vaccine admixture of mannan and flu antigen. Aust patent 037033 A1.

Ramli, N., Wiryawan, K.G., \& Tafsin, M. (2005). Daya hambat polisakarida mengandung mannan yang diekstraksi dari bungkil inti sawit terhadap Salmonella spp. dan E. coli secara in vitro. Prosiding Seminar Nasional Asosiasi Ahli Ilmu Nutrisi dan Pakan Indonesia (AINI) V. Universitas Brawijaya, Malang.

Ross, A., et al. (2001). Human IgA activates the complement system via the mannan binding lectin pathway. J Immun 167, 286-2868.

Sauerwein, H., Schmitz, S., \& Hiss, S. (2007). Effect of a dietary application of a yeast cell wall extract on innate and acquired immunity, on oxidative status and growth performance in weanling piglets an on the ileal ephithelium in fattened pigs. $J$ Anim Phys Anim Nutr (Abst) (on line early articles).

Savage, T.F., Cotter, P.F., \& Zakrzewska, E.I. (1996). The effect of feeding a mannan oligosaccharide on immunoglobulins plasma IgG and bile IgA of Wrolstad MW male turkeys. Di dalam: Lyons, T.P., Jacques, K.A., editor. Biotechnology in the feed industry. Proceedings of Alltech 12 ${ }^{\text {th }}$. Annual Symposium. (pp. 16-19). Nottingham University Press, Nottingham.

Shafey, T.M., Al-mufarez, M., Shalaby, I., \& Jarlenabi, A.J. (2001). The effect of feeding mannanoligosaccharides (BioMOS) on the performance of meat chicken under two different vaccination programs. Asian-Australasian Journal of Animal Sciences, 14, 559-563.

Spearman, K.R. (2004). Effect of mannanoligosaccharide (MOS) supplementation on the immune status of mares and their foals [thesis]. University of Florida, Florida.

Tafsin, M. (2007). Kajian Polisakarida Mannan dari Bungkil Inti Sawit sebagai Pengendali Salmonella thypimurium dan Immunostimulan pada Ayam [disertasi]. Sekolah Pascasarjana, Institut Pertanian Bogor, Bogor.

Takahashi, K., Mashiko, T., \& Akiba, Y. (2000). Effect of dietary concentration of xylitol on growt in male broiler chicks during immunological stress. Poult Sci 79:743-747. 
Tizard, I.R. (1982). Pengantar Imunologi Veteriner. Penerjemah. Partodiredjo, M., \& Hardjosworo, S. Terjemahan dari: An Introduction to Veterinary Immunology. Airlangga University Press, Surabaya.
Waldroup, P.W., Edgar, O., OviedoRondon, \& Fritts, C.A. (2003). Comparison of Bio-MOS and antibiotic feeding programs in broiler diet containing cooper sulfate. International Journal of Poultry Science, 2, 28-31. 